\title{
The Pictures Which Children Drew Are Their Mirrors!
}

\author{
Çocukların Çizdiği Resimler: Onların Aynasıdır!
}

\author{
İlkay KAYACAN KESER, ${ }^{1}$ Nurhan EREN ${ }^{2}$
}

\begin{abstract}
SUMMARY
Both Freud and Jung, who are the ancestors of modern psychology, pointed out the reciprocal link between art, symbols and personalities in their studies. Freud confirmed with his studies that universal human conflicts and neurosis drive people into the artistic creativity and the expression by drawing is a way to understand the inner world of the human spirit. Jung searched the universality and archetypes contained in the visual arts as he believed that the connection is important between the soul and the image and also he stressed the importance of symbols in description. Jung stated that imagines develop the spirit as creating symbols and individuals exposed to trauma treat themselves by using this way. In parallel with Freud's and Jung's studies, different studies were made as a result of orientation to the pictures of children. In the several studies from the past to the present, pictures are one of the most important ways of expressing themselves for children, in addition to this; it is an indicator for the emotional and cognitive development of children. It is stated that children reflect the inner world of their own as spontaneous and without resistance in the pictures which they draw, and they perceive this activities as a game, and inform the advisor about their psychological status, forms of interpersonal relationship, feelings, briefly many information related with their inner world. It is also specified that drawing is an easy communication instrument especially for the children who are timid, passive and have difficulties in expressing themselves; and it gains an important power to counselor about understanding children.In this review, we tried to tell the therapeutic use of pictures to assess the children mental status and the studies which was made in this subject in our country and the world.
\end{abstract}

Keywords: Children's mental health; children's picture, reflection of pictures.

\section{ÖZET}

Modern psikolojinin atalarından olan Freud ve Jung'un her ikisi de yaptıkları çalışmalarda sanat, semboller ve kişilik özellikleri arasındaki karşııılı bağlantıya dikkat çekmişlerdir. Freud, insanlardaki bilinçdışı çatışmaların ve nevrozun, insanları sanatsal yaratıcılığa yönlendirdiğini, resimle anlatımın insan ruhunun iç dünyasını anlamaya giden bir yol olduğunu yaptığı çalışmalar ile doğrulamıştır. Jung, ruh ve imge arasındaki bağlantıyı incelemiş, kolektif bilinçaltını ve arketipleri araştırmış, görsel sanatın içerdiği betimlemedeki evrensel sembollerin kişinin ruhsal dünyasına ulaşmada önemini vurgulamıştır. Jung, hayal gücünün semboller yaratarak ruhu geliştirdiğini, travmaya maruz kalmış bireylerin bu yolla kendini iyileştirdiğini belirtmiştir. Freud ve Jung'un çalışmalarına paralel olarak, çocuk resimlerine olan yönelim sonucunda farklı çalışmalar yapılmıştır. Geçmişten günümüze yapılan bir çok çalışmada, resimlerin çocukların kendini ifade edebildiği en önemli yollardan birisi olmasının yanı sıra, çocukların duygusal ve bilişsel geliş̧imlerinin bir göstergesi de olduğu vurgulanmaktadır. Çocukların çizdiği resimlerde, kendi iç dünyalarını spontan ve direnç göstermeden yansıttıkları ve bu etkinlikleri oyun olarak algıladıkları, resimler aracılığı ile danışmana psikolojik durumları, kişilerarası ilişki biçimleri, yaşadıkları duyguları, kısacası iç dünyaları ile ilgili bir çok bilgiyi aktardıkları belirtilmektedir. Bazı çalışmalarda ayrıca, boşanma, terk edilme, istismara uğrama gibi birçok travmatik yaşam olayının çocuğun bilişsel, sosyal ve ruhsal gelişimini olumsuz etkilediği belirtilerek bu etkilenmenin, çocukların çizimlerine ve oluşturdukları figürlere doğrudan yansıdığı vurgulanmaktadır. Resmin özellikle kendisini ifade etmekte zorlanan çekingen, pasif çocuklar için kolay bir iletişim aracı olduğu ve çocukları anlamada danışmana önemli bir güç kazandırdığı belirtilmektedir. Bu derleme çalışmasında, literatür bilgileri ve olgular aracılığıyla, çocukların ruhsal durumlarını değerlendirmede resmin terapötik kullanımı, dünyada ve ülkemizde bu konuya ilişkin yapılan çalışmalar aktarılmaya çalışılmıştır.

Anabtar sözcükler: Çocuk ruh sağgl̆ğı; çocuk resimleri ve resimlerin yansıttıkları.

\section{Introduction and Aim}

The importance of drawing, which is a freeform and simple way of conveyance for the reflection of both a child's inner world and his/her attitudes and beliefs upon events, is huge.

'Department of Psychiatric Nursing, Akdeniz University Faculty of Nursing, Antalya

${ }^{2}$ Department of Psychiatry, Social Psychiatry Service, Istanbul University Istanbul Faculty of Medicine, İstanbul

Correspondence (illetişim): Dr. Illkay KAYACAN KESER. e-mail (e-posta): ikeser@akdeniz.edu.tr

Psikiyatri Hemşireliği Dergisi 2015;6(3):137-142

Journal of Psychiatric Nursing 2015;6(3):137-142

Doi: $10.5505 /$ phd.2015.85547

Submitted (Gelis tarihi): 16.02.2015 Accepted (Kabul tarihi): 02.09.2015
Drawing is a candid narrative for children that can be used to reflect their emotions, thoughts, perceptions and observations. By exhibiting their perceptions of the outside world in their pictures, children give many clues to their inner world. Drawing, which is a projective technique used to give meaning to the perceptions and emotions of children, is a widely used method in pediatrics clinics. ${ }^{[1]}$ However, the use of this method is not very widespread in our country. It is generally used by psychologist or pediatric psychiatrists as a method that helps in diagnosis. When the responsibilities, duties, and authorizations of a children and adolescents' nurse are examined, it can be seen that the nurse is expected to analyze the child and the socio cultural environment he or she is in, and manage a planned care process that aims to protect and improve the health of the child. In this context, children's draw- 
ings can be considered to guide the nurse in planning and executing the interventions to the child. In this compilation, the goal was to stress the importance of the subject by referring to the therapeutic use of drawings in the evaluation of the mental status of children in studies throughout the world.

\section{Children's Drawings From the Past to Today}

In their studies, both Freud and Jung from among the forerunners of the psychoanalytic theory have drawn attention to the correlation between art, symbols, and personality characteristics. Freud (1995), through his studies, confirmed that unconscious conflicts and neurosis in people draw people toward artistic creativity and that expression through drawing is a path to understanding the inner world of a human being. ${ }^{[2]}$ Jung (2003) examined the connection between mind and image, researched collective subconscious and archetypes, and stressed the importance of universal symbols in visual arts in reaching the inner world of a person. Jung stated that the imagination improves the soul by creating symbols and that individuals exposed to trauma thus heal themselves. ${ }^{[3,4]}$ Parallel to Freud and Jung's work, various studies on children's drawings were performed. In many studies throughout the years, it was stressed that besides being one of the most important ways of self expression, drawings are also indicators of children's emotional and cognitive development. The reflections of the socio cultural structure the children live in in their drawings were evaluated. ${ }^{[3]}$ In England and Germany at the end of the 19th century the physical and emotional development of children were examined alongside their interpretive formation effectiveness development in drawing. ${ }^{[5-7]}$ In later studies, classification and identification in children's drawings were examined. As a result of his studies on school children, Kerschenstiner (1905) categorized drawings according to age criteria as schematic, visual, and three dimension representational drawings. ${ }^{[8]}$ Additionally, Klepsch and Logie in their "Children Draw and Tell" work, stated that lines in children's drawings could be psychologically interpreted in three ways, namely size, exaggeration, and missing lines. ${ }^{[9]}$ In the beginning of the $20^{\text {th }}$ century, it was concluded that children go through three phases in drawing, namely scribbling, schematics, and naturalistic. ${ }^{[3]}$ Children, as in all other dimensions of development, pass through the same phases in the same ages regarding art development. The lines that are meaningless in earlier ages turn into meaningful pictures in time. With a very generalized approach, as children grow older their pictures become more detailed, better proportioned, and more realistic. Each phase of drawing development also has some striking characteristics that define the drawings. The development of children's drawings is monitored in five phases today. These are the scribbling phase (ages 2-4), the pre schematic phase (ages 4-7), the schematic phase (ages 7-9), the realism (grouping) phase (ages 9-12), and the apparent naturalism phase (ages
12-14). ${ }^{[6]}$ The pictures reflecting the characteristics of those phases were given in Figure 1-5. Piaget stated that human intelligence passed through certain processes with age and that each step contains more complex or novel cases compared to

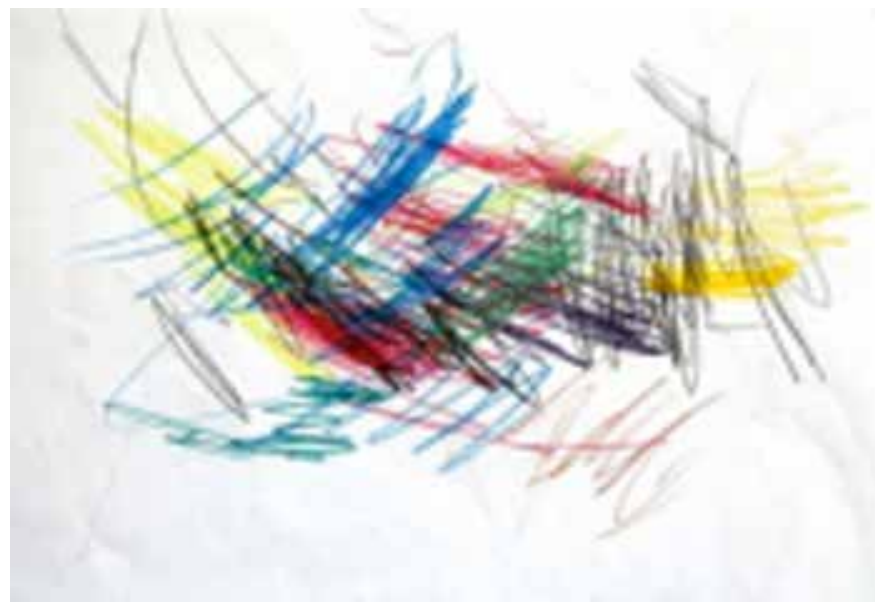

Figure 1. The scribbling phase (ages 2-4).

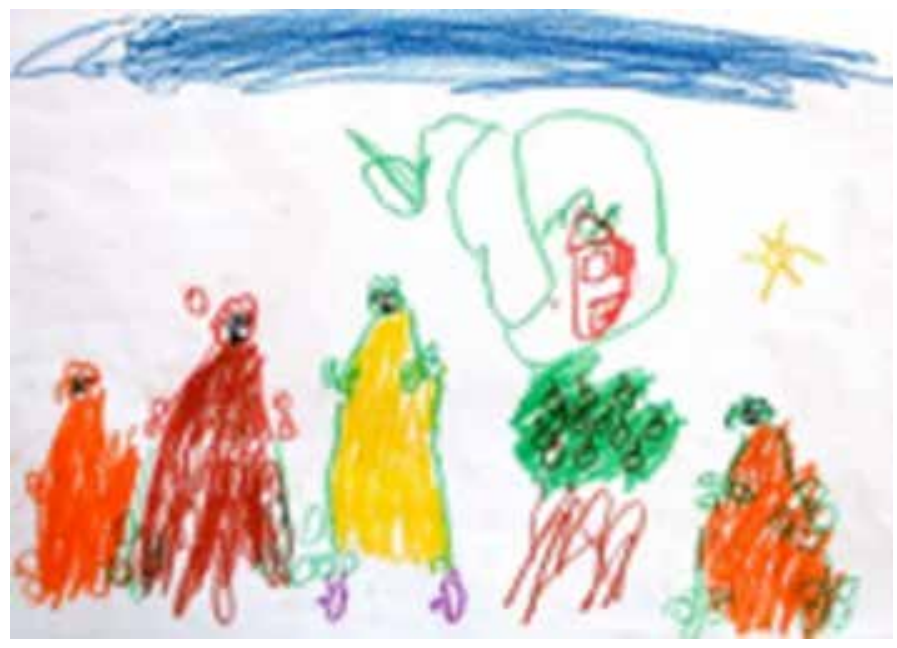

Figure 2. The pre schematic phase (ages 4-7).

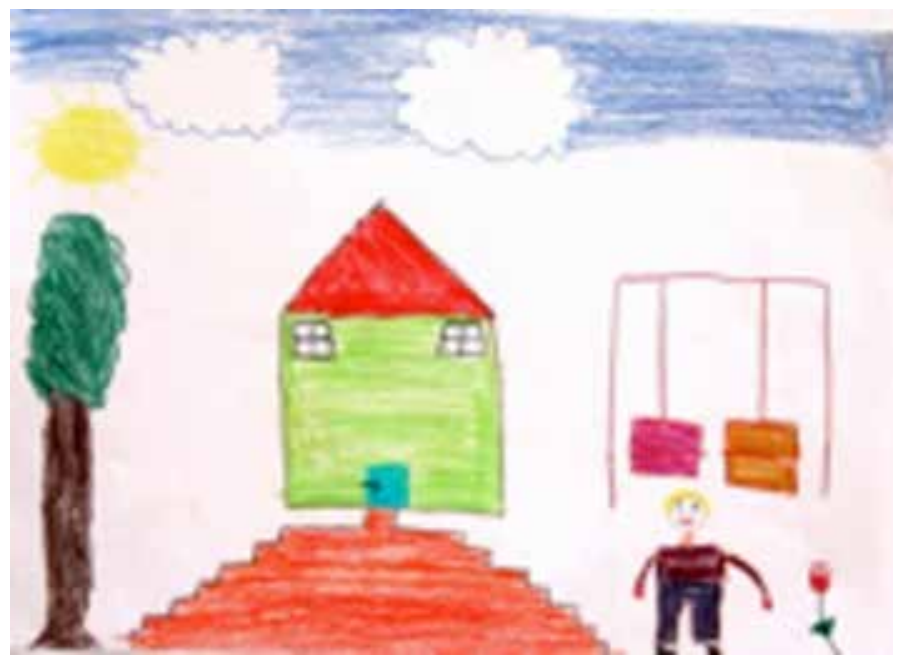

Figure 3. The schematic phase (ages 7-9). 


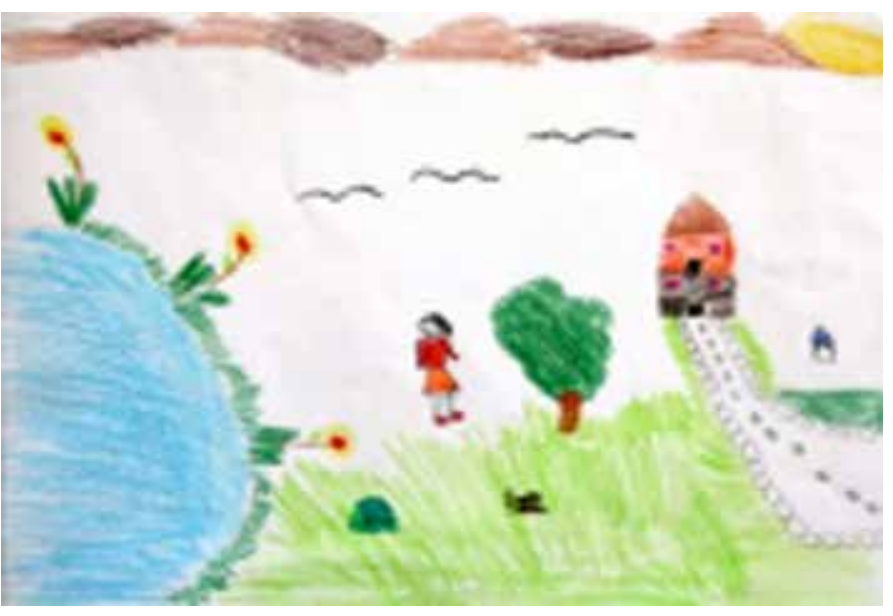

Figure 4. The realism (grouping) phase (ages 9-12).

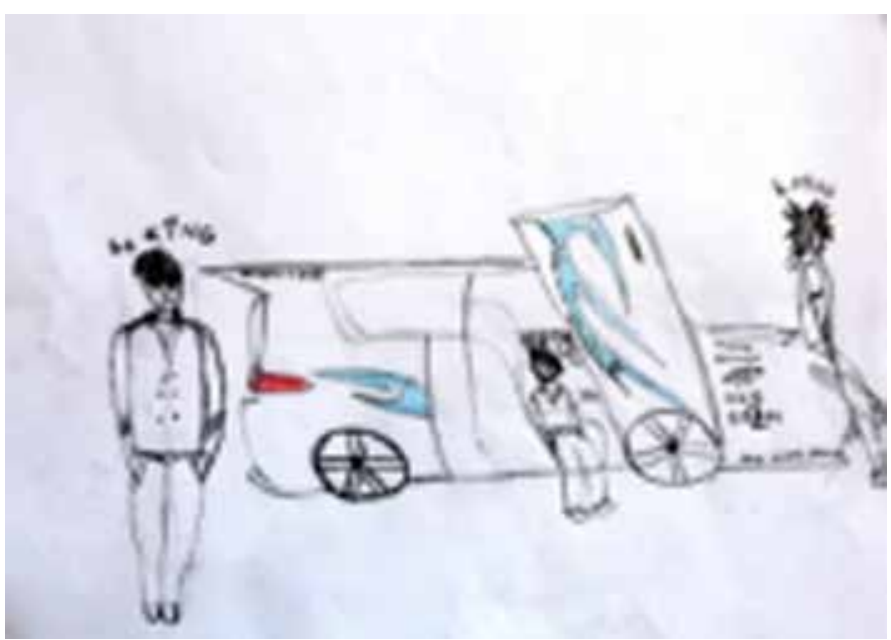

Figure 5. The apparent naturalism phase (ages 12-14).

the last. He stated that maturing and biological changes were responsible for cognitive changes, and explained cognitive development in four stages. These are the sensory stage (ages $0-2$ ), the pre operational stage (ages 2-7), the tangible operations stage (ages 7-12), and the formal operations stage (age 12 and above). ${ }^{[10]}$ Piaget anmed the thoughts and beliefs of children about objects, which are the cognitive constructs in the children's world, as schematics. He stated the characteristics of each stage and stressed that the schematics develop in stages. [11] The development stages in children's drawings are directly related to the cognitive development stages stated by Piaget.

\section{What Children's Drawings Tell Us?}

Children reflect the characteristics of the environment they live in and the meanings they form in this environment in their drawings. Children's drawings usually exhibit the environment of the child and his or her family, parent, and sibling relationships. According to Marett, there are no coincidences in pictures and everything is mandatory. ${ }^{[11-14]}$ Each picture exhibits the emotional state, unconscious movement or answering manner of a subject as a symbolic riddle. ${ }^{[15]}$
Children also exhibit symbols regarding their emotional and intellectual lives in their drawings. Children have an inner world containing conflicts with the world of social and objective truths, desires, happiness, and anxieties. The child, who can explain his or her emotions and thoughts regarding the world of truths through a common language may not always be able to explain his or her thought and emotions regarding his or her own inner world with this language. ${ }^{[16]}$ Thus, drawing is both a pastime and a narrative technique for some children. ${ }^{[1,17]}$ In various studies, children were found to reflect their inner world spontaneously and without resistance through drawing, perceive these activities as games, and convey information to the counselor regarding their psychological status, interpersonal relationships, their emotions and their inner world in general. In the same studies, many traumatic life events such as divorce, abandonment, and abuse were stated to affect the cognitive, social, and emotional development of children, and these effects were stated to be directly reflected in their drawings and figures. ${ }^{[12,13,17,18-22]} \mathrm{Ea}-$ ton et al. (2007) suggested the use of art therapy techniques to ease the psychological difficulties of children exposed to trauma. ${ }^{[23]}$ In many studies using different art therapy techniques in our country, these techniques were stated to be effective in coping with the difficulties of being an inpatient. [24-27] Clatworthy et al. (1999) stressed in their study that in children, who can express their emotional states in a more limited manner verbally compared to adults, drawing, which is a projective method, should be used. ${ }^{[28]}$

A drawing gives information on emotional and cognitive development, and helps hidden traumas, vague and conflicted emotions, fears, conflicts, and perceptions to clearly present. [3,19,29] Brinkman (2004) wanted children with asthma to describe their illness via drawing, and some of the children drew weights on their chests, or a hand choking them underwater. ${ }^{[30]}$ Another child drew a monster enveloping his chest, preventing his breathing. As a result of his research Stuyck (2003) asked sick children what they thought about their disease or being inpatients and found that they had difficulty answering verbally, while they conveyed the case through drawing clearly. ${ }^{[31]}$ In a study by Beebe et al. (2010), the emotional load related to having a chronic disease was evaluated in children with asthma using art therapy methods, and the problem solving steps were evaluated. As a result a positive change regarding anxiety levels and quality of life was found between the control and study groups, differences between their problem solving abilities, symptom management, and anxiety levels were found, and art therapy was found to be beneficial in children with asthma. ${ }^{[32]}$ According to Karadağ and Uğur (2015) in art therapy applications performed with children with cancer through painting, joy and concern, peace and difficulty all may come together in children's drawings. As 
their health condition gets worse, the lines become mixed up, the colors become darker, emotions disappear, scribbling appears, and hope is mostly conveyed through a sun, tree, road, house, or vibrant colors. ${ }^{[33]}$ In another study, social skill training was given through art therapy and group therapy to children with autism, and the behavioral changes in the children were evaluated. As a result of the study, positive behavioral changes and a reduction in problematic behavior was seen. ${ }^{[34]}$

Drawing helps the therapist or nurse overcome difficulties in communicating with children, makes it easier for the child to express his or her feelings, and makes it possible to discover the problems under the surface. It increases he imagination and creativity of the child, improves his communication skills, and increases his self respect and self confidence. [30,31,35] Self respect can be identified in children's drawings by searching for smaller figures and sloppy scribbling. In a study by Abdi et al. (2004) in which these criteria were used for interpretation, children with hearing disabilities (control) with cochlear implants (experiment) were monitored for a year and the self respect signs in the drawings they made were examined monthly. While the low self respect rate in children in the experiment group was $42.9 \%$ in the third month, it receded to 21.5 by the end of the twelfth month. The results of the study show that drawing makes it easier for children to express their feelings and that it provides an opportunity for children to exhibit clues about themselves such as low self respect. ${ }^{[36]}$ In a study where Keser (2013) examined the effects of assertiveness training on assertiveness skills and self respect, an increase in the assertiveness skills and self respect was seen through data obtained in children's drawings, and this change also produced positive changes in the drawings with regard to shape, content, and composition. ${ }^{[37]}$

A child who has difficulty verbally telling his story can expose information on himself, his environment, and his family through drawing and painting. ${ }^{[13]}$ In children's drawings, the symbols of house and family are seen very often. In a family picture with harmony, the members are shown doing something together or holding hands. Two or more people standing together show a real connection or a connection desired by the child. The child draws himself next to whoever he feels most comfortable with. This may also be the person the child loves the most. If the child has a fractured family, feels alone in the family or thinks his family doesn't love him, he may express this in different manners. He may draw all the members in separate rooms or may separate the members with lines, trees, or fences. The hose can be drawn as split in two or two separate houses in children with fractured families. The parent who left home may not be present in the paintings. These children may sometimes paint a happy family picture. Children from fractured families may try to express their longing by drawing a happy family picture with both parents. ${ }^{[13,19,20,38-40]}$
Drawing increases the speaking and expression skills of children. Pictures are a more effective way for children to convey the experiences that emotionally affect them compared to verbal expression. As a result of a study they performed in order to find whether drawing makes verbal communication easier in children, Gross and Haynes (1998) found that drawing increases children's communication skills, emotions, and perceptions. ${ }^{[40,41]}$ In the study, children who were provided with an opportunity to draw while speaking gave more information when compared to children who were only speaking. In the second part of the study, the two procedures were applied to children at the same time, and children who were asked to draw were found to convey more information. As a result of the study, drawing was found to be a tool for easy communication especially for children who had difficult expressing themselves and were passive, and give important power to the counselor in understanding children.

Another aspect of drawing is that certain emotions of children, such as aggression, grow weaker while drawing. The child both expresses his or her feelings while drawing and reaches emotional comfort. Aggression findings in drawings can be identified by heavy scribbling, pressed and incomplete lines, big field paintings that cover all of the page, and definitive drawing of teeth. ${ }^{[41-43]}$ In studies, children were found to be able to express many emotions and thoughts they couldn't verbally convey with drawing, leave their aggressive attitudes and behaviors aside, and direct their energies into more beneficial activities. ${ }^{[4,45]}$ In a study performed to examine the effects of being an inpatient in children, Beytut et al. (2009) found that findings of aggression were higher in children with chronic diseases compared to the healthy and acute groups, and that this finding means a higher level of anger felt by the children towards their experiences in the hospital. ${ }^{[46]}$ In another study, the aim was to evaluate the pre operational anxiety levels of children through drawing and the result was that children who were agitated had different drawings and anxiety scores compared to others. As a result of the study, it was suggested that premedication could be done according to the children's needs and not routinely. ${ }^{[4]}$

\section{Evaluation of Children's Drawings}

As is the case in other projective techniques, psychodynamic and cognitive theories are used in the evaluation of children's drawings. Drawing skill is known to show developmental characteristics with age both with regard to the representation of physical truth and artistic expression. Thus, the child's development stage should be taken into consideration and the effects of characteristics regarding the development of drawing should be evaluated. ${ }^{[4]}$ Various test are present that identify the criteria for the emotional, cognitive, perception related and neuropsychological development levels of children. One of the first known tests, the 
"Draw a Man" test, was developed by Florence Goodenough (1926) and later developed in manner that aims to measure the cognitive development of individuals by GoodenoughHarris (1963). The latest version of this test is the "Draw a Person" test by Machover (1949) developed to evaluate personality traits. This is one of the tests used to understand the personality and emotional state of a child. Questions about the picture are asked to the child after drawing is complete. These questions explain the identities and characteristics of the person drawn. The application of the questions is performed according to the age and answer context of the person making the drawing. The drawing as a measure of cognitive development approach is based on the concept development process. The concept development process is the whole of processes such as the perception of the environment and objects in the environment, the identification of objects, the isolation of objects from others, classification of objects according to basic characteristics, and generalization. The draw a man test is used as a complementary to StanforBinet and other verbal scales. While evaluating these tests, cases such as the size of the drawing, exaggerated lines, missing lines, the position of the drawing within the page, the order in which the objects were drawn, the missing or excessive drawing of organs etc. are examined. The behavior of children during drawing is also examined. The method of communication, cooperation with the counselor, motivation, use of the pen, what the child says, which part the drawing starts from, which body parts the child spends more effort in, erasings, tendency to correct, which parts are watched more, the size and position of the drawing on the page, and the duration of drawing should all be examined and noted without making the child uncomfortable. All of these findings reflect the intelligence as well as the neurocognitive and emotional development of the child. ${ }^{[41-44,46-50]}$

Drawing may be considered as the way an individual explains his or her complex world and an indicator of cognitive development. Spontaneous drawings, since they reflect one's inner world, can provide detailed clues on children and their development when analyzed appropriately. ${ }^{[6,18]}$ While using this language, the child reflects his perceptions of the environment fearlessly. The way to increase understanding of the meanings of the drawings of children is to talk to them about the drawings. ${ }^{[3]}$ Children are more inclined to draw what they "know" instead of what they "see". ${ }^{[43,46,50]}$ Thus, the best way to understand the message in children's drawings is to talk to children about the drawings.

The process of drawing requires a child to synthesize many components such as content, style, shape, and composition in order to convey a thought, feeling, or observation and select and organize colors, shapes, and lines. ${ }^{[3]}$ While hot colors (red, orange, and yellow) in a picture give warmth, life, joy, and movement, cold colors (blue, green, and purple) have a calming and easing effect. ${ }^{[13,19,20]}$ While the use of hot colors is interpreted positively, the heavy use of red is usually interpreted as aggression. Black explains fear, red explains aggression, the use of blue, brown, and orange explains fear, depression, and anger ${ }^{[3]}$ If everything in a picture is black and red, this show that the child is doubtful while the use of pink, red, and green together shows a healthy approach. ${ }^{[51,52]}$ In a study by Burkitt and Newel (2005), happy children were found to use yellow and orange often while black and brown was chosen by unhappy children. ${ }^{[53]}$ In a study by Abdi et al. (2004), children with higher levels of anxiety were found to use red more, pressing more on the pen. Color selection was also examined in the study, and hot colors were found to be used most by children with acute diseases with high anxiety. ${ }^{[36]}$

\section{Conclusion and Suggestions}

For children, drawing is a process that incorporates many different experiences with the aim of creating something individualized, unique, and new. Working through drawings is generally identified by experts working with children as a very enlightening, unique, and fun process. ${ }^{[54]}$ Studies show that supporting information on children with drawings is very helpful in diagnosis and treatment. Children's drawings help the related behavior appropriately surface, speeding up the process of health professionals helping the child.

As a result, children's drawings may help nurses who work with children to understand the complexity of the child's family cycle, life stressors, traumatic events, and crises. Nurses can thus evaluate the needs of the child and his or her family regarding coping and problem solving, maintain therapeutic communication required for coping with concern, sadness, anger, guilt, and helplessness in a healthy manner, and use the drawings as a mirror for the selves of children when planning for care. Drawing is thought to be an easy method of communication especiallyfor passive and shy children that have difficulty expressing themselves, and can bring the nurse much needed power in understanding children. Thus, it is suggested that nurses who work with children should use drawing materials, which is a projective method, when communicating with children.

\section{References}

1. Johnson BH. Children's drawings as a projective technique. Pediatr Nurs 1990;16:11-7.

2. Freud S. Sanat ve sanatçılar üzerine. (Şipal K, Çeviri Editörü) İstanbul: Yapı Kredi Yayınları 1995.

3. Malchiodi CA. Çocukların resimlerini anlamak. (Tülin Yurtbay, Çeviri Editörü) İstanbul: Epsilon Yayıncılık 2005.

4. Jung CG. Dört arketip. (Yılmazer ZA, Çeviri Editörü) İstanbul: Metis Yayınları Ötekini Dinlemek; 2003.

5. Güney M. Sanat terapileri. Türkiye Klinikleri Psikiyatri Özel Dergisi 2009;2:84-90.

6. Yavuzer H. Resimleriyle çocuk. İstanbul: Remzi Kitabevi 2003:11-67. 
7. San İ. Sanatsal yaratma ve çocukta yaratıcılık. Ankara: T. İş. Bankası Kültür Yayınları1979.

8. Şenel S. Çocuk resminde aile ve plan algısı. (Yayınlanmamış yüksek lisans tezi) İstanbul:MarmaraÜniversitesi,Sosyal Bilimler Enstitüsü, Resim-İş Eğitimi Sanat Dalı 1995:3-41.

9. Klepsch Logie. Children draw and tell: an introduction to the projektive uses of children's human figure. New York: Brunner Mazel Inc.; 1982.

10. Videbeck SL. Psychosocial theories and therapy. In: Videbeck SL, Psychiatric mental health nursing New York: Lippincott Wlliams \& Wilkins; 2011. p. 43-60.

11. Bilham S. Using developmental theories to enhance holistic care. In: Thurston C, Essentials nursing care for children and young people London: Routledge Taylor \& Francis Group; 2013. p. 74-86.

12. Barraza L. Children's drawings about the environment. Environmental Education Research 1999;5:49-66.

13. Hague E. Nationalty and childrens' drawings - pictures 'about Scotland' by primary school children in Edinburg, Scotland and Syracuse, New York State. Scottish Geographical Journal 2001;11:77-99.

14. Ring K. What mothers do: Everyday routines and rituals and their impact upon young children's use of drawing for meaning making. International Journal of Early Years Education 2006;14:63-84.

15. Belet YD, Türkkan B. İlköğretim öğrencilerinin yazıı anlatım ve resimsel ifadelerinde algı ve gözlemlerini ifade biçimleri (Avrupa Birliği örneği). VI. Ulusal Sınıf Öğretmenliği Eğitimi Sempozyum Bildirileri. Ankara: Nobel Yayın Dağıtım; 2007.

16. Yavuzer H. Resimleriyle çocuk. İstanbul; Remzi Kitapevi; 2013.

17. Kırışlıoğlu O. Sanatta eğitim-görmek, öğrenmek, yaratmak. (ikinci Basım). Ankara: Pegem Yayıncilık; 2002.

18. Çiçekler YC, Koruklu ÖN. Features of the Drawings of 4-6 Year Old Children in their Free Drawings. Hacettepe Üniversitesi Eğitim Fakültesi Dergisi [Hacettepe University Journal of Education] 2013;28:551-63.

19. Doğru SY, Turcan Al, Arslan E, Doğru S. Çocukların Resimlerindeki Aileyi Tanılama Durumlarının Değerlendirilmesi. Erişim adresi: http://www.sosyalbil.selcuk.edu.tr/sos_mak/makaleler/Erişim Tarihi: 03.08.2012.

20. Artut K. Sanat eğitimi-kuramlar ve yöntemleri, Ankara: Anı Yayıncılık; 2004.

21. Aydın B. Tıbbi sanat terapisi. Psikiyatride Güncel Yaklaşımlar-Current Approaches in Psychiatry 2012;4:69-83.

22. Keskin SP. Çocuk çizgilerindeki giz, çöp çocuk. İstanbul; Boyut Yayıncılık; 2007.

23. Eaton LG, Doherty KL, Widrick RM. A review of research and methods used to establish art therapy as an effective treatment method for traumatized children. The Arts in Psychotherapy 2007;34;256-62.

24. Şahan DE. Çocuk hastaların hastaneye ilişkin korkuları ve korkuyu etkileyen etmenlerin incelenmesi. Ege Üniversitesi Hemşirelik Yüksekokulu Dergisi 1997;26:247-8.

25. Tunç A. Ergenlerin olumsuz beden imgelerine yönelik geliştirilen bilişseldavranışçı ve değiştirilmiş sanat terapisi programlarının etkililiklerinin karşılaştıııması. (Yayınlanmamış yüksek lisans tezi) Ankara; Ankara Üniversitesi Sosyal Bilimler Enstitüsü Tiyatro Çocuk Tiyatrosu, Oyun-TiyatroDrama Anabilim Dalı 2007

26. Yılmaz U, Oltuoğlu H, Hanazay B, Aylaz R. Uğraş terapisinin kronik hastalıklı çocukların durumluluk kaygı düzeylerine etkisi. Uluslar Arası Katılımlı 3. Ulusal Pediatri Hemşireliği Kongresi. DEÜ Sabancı Kültür Sarayı, İzmir. Kongre Özet Kitabı, Sözel Bildiri 2011.

27. Teksöz E, Ocakçı AF. Çocuk hemşireliği'nde sanat uygulamaları. DEUHYO ED 2014;7:119-23.

28. Clatworthy S, Simon K, Tiedeman ME. Child drawing: hospital--an instrument designed to measure the emotional status of hospitalized schoolaged children. J Pediatr Nurs 1999;14:2-9.

29. Wallace $K$. Art therapy creativity groups and Individual counselling erişim tarihi 25.09.2012 http://www.islandnet.com/ kwallace/index.htm.
30. Brinkman J. Art therapy with children-a window to their world 2004. Erişim: 25.09.2012 http://www.uchsc.edu/news/bridge/2004/April/arttherapy.html.

31. Stuyck K. Art therapy helps children affected by cancer express their emotions. Oncology 2003;48:1-4.

32. Beebe A, Gelfand EW, Bender B. A randomized trial to test the effectiveness of art therapy for children with asthma. J Allergy Clin Immunol 2010;126:263-6.

33. Karadağ E, Uğur Ö. An Application Very Unspoken In Cancer Patients: Art Therapy. DEUHFED 2015;8:142-4.

34. Epp KM. Outcome-based evaluation of a social skillsprogram using art therapy and group therapy for children on the autism spectrum. Children Schools 2008;30:27-36.

35. Waller D. Art therapy for children: how it leads to change. Clin Child Psychol Psychiatry 2006;11:271-82.

36. Abdi S, Jalili B, Tavakoli $\mathrm{H}$, Naderpour M. Emotional changes in children undergoingcochlear implantation though evaluation of their drawinngs. Iran J Med Sci 2004;29:62-6.

37. Keser İ, Barlas ÜG. Evaluation of The Effectiveness of Assertiveness Training for Physically Handicapped Adults on Body Image, Self-Esteem and Attitudes Directed to Themselves Marmara University, Faculty of Health Sciences, Division of Nursing, İstanbul MÜSBED 2014;4(Suppl. 1):19.

38. Hobday A, K Ollier. Creative therapy with children \& adolescents. Atascadero, CA: Impact Publishers 1999.

39. Niolon R. Notes on projective drawings. Erişim: 23.09.2012 http://www. psychpage. com/projective/proj draw_notes.html.

40. Process of Art Therapy with Children Heather Vale Goss Oct 27, 2009 http://www.livestrong.com/article/30087-process-art-therapy-children/ erişim tarihi 25.09.2012.

41. Gross J, Haynes H. Drawing facilitates children's verbal reports of emotionally laden events. J Exp Child Psychol 1998;4:163-79.

42. Dizman H, Gültekin G, Akyol A. Çocukları tanımada resimlerin önemi. Adli Psikiyatri Dergisi 2005;2:23-30.

43. Saydam RB. Çocuk çizimlerinin klinik değerlendirmedeki yeri. Yansıtma, Psikopatoloji ve Projektif Testler Dergisi 2004;1:111-24.

44. Paksoy S. 8-12 yaş eğitilebilir zihinsel engelli çocukların resim-iş eğitimi. (Yayınlanmamış yüksek lisans tezi.) İstanbul; Marmara Üniversitesi Eğitim Bilimleri Enstitüsü Güzel Sanatlar Eğitimi Ana Bilim Dalı Resim Öğretmenliği Bilim Dalı 2003.

45. Hamama L, Ronen T. Children's drawings as a self-report measurement. Child and Family Social Work 2009;14. p. 90-102.

46. Beytut DŞ, Bolışık B, Solak U, Seyfioğlu U. Çocuklarda hastaneye yatmaya etkilerinin projektif yöntem olan resim çizme yoluyla incelenmesi. Maltepe Üniversitesi Hemşirelik Bilim ve Sanat Dergisi 2009;2:35-44.

47. Puura A1, Puura K, Rorarius M, Annila P, Viitanen H, Baer G. Children's drawings as a measure of anxiety level: a clinical pilot study. Paediatr Anaesth 2005;15:190,3.

48. Cox S. Intention and meaning in young children's drawing. International Journal of Art \& Design Education JADE 2005. p. 115-25.

49. Çocuk Değerlendirmenin Genel Esasları. Aile Danışmanları Derneği, Aile Danışmanlığı Eğitimi Ders Metaryali Antalya 12 Şubat 2011.

50. Toomela A. Generic represantations in children's drawings. TRAMES 2006;10:341-54.

51. Ersoy A, Türkkan B. Perceptions about Internet in elementary school children's drawings. Elementary Education Online 2009;8:57-73.

52. Drawings.by the Institute for psychological therapies. http://www.iptforensics.com/library/images5.htm. Erişim tarihi 28.08.2012.

53. Burkitt $E$, Newel T. Effects of human figure type on children's use of colour to depict sadness and happiness. International Journal of Art Therapy 2005;10:15-2.

54. Art Therapy Creativity Groups and Individual Counselling http://www.islandnet.com/ kwallace/index.htm Erişim Tarihi 25.09.2012. 